\title{
THE ROLE AND IMPORTANCE OF CELEBRITIES IN ACHIEVING CUSTOMER SATISFACTION AND LOYALTY
}

\begin{abstract}
The aim of this research is to gain a better insight into customer satisfaction and loyalty as a result of celebrity brand endorsements, based on the data collected through primary and secondary research. The paper explores the concept of brand, as well as consumer attitudes towards brands and the use of celebrities in advertising. A brand is a name, symbol or design that identifies a product or service that is commonly associated with quality. In today's market, celebrities are a vital element of brand advertising and a major factor in driving product sales. New media advertising has become essential for successful communication with the contemporary consumer.
\end{abstract}

Key words: celebrity, advertising, brand management, customer satisfaction, customer loyalty

\section{Introduction}

More and more businesses are utilising new media in their advertising campaigns because they are interactive; allow accurate measurement of the effectiveness of promotion; reach wider audiences faster; provide the ability to target audiences with precision; and are less expensive than traditional media. Featuring celebrities in ads increases their effectiveness and boosts brand sales. A celebrity is a person who has significant influence in areas such as art, film, music, sport, culture or politics. A celebrity status is not always earned by being successful in a particular profession. A person can become a celebrity by just looking beautiful and frequenting fashionable places and events. Celebrity endorsements are a powerful tool in brand advertising,

* Sanjica Pavlović, mag. oec., University North, Varaždin, pavlovic.sanjica@gmail.com

** doc. dr. sc. Dijana Vuković, University North, Varaždin, dvukovic@unin.hr

*** izv. prof. dr. sc. Anica Hunjet, University North, Varaždin, ahunjet@unin.hr 
especially in high fashion. Their influence is so powerful that they can make or break a brand. One of the reasons marketers engage celebrities in promoting a brand is to make their message stand out from competitors' messages in the ad cluttered market, and to build and maintain brand credibility. To increase brand success, many marketers hire ambassadors. An ambassador is a person who represents a brand, raises public awareness, thus increasing sales. Celebrity endorsement, where celebrities share their opinions and experiences, recommend or are seen using a product, has become a powerful marketing strategy. With the advent of the modern society came the consumer culture. To attain a certain lifestyle, we are constantly in the pursuit of things that we see in commercials.

\section{Celebrities and advertising}

Advertising is any paid form of communicating information to the public aimed at directly or indirectly affecting product or service sales. It is a paid form of non-personal presentation and promotion of ideas, goods and services by an identified sponsor. In contrast to advertising, as a paid form of promotion whose purpose is to present a product or service to a wider audience in order to achieve communicative and economic benefits, public relations is unpaid promotion through the mass media coverage. Advertising communication involves presenting opinions and ideas aimed at influencing consumers and their opinions by a sponsor which is, typically, known and identifiable or named in the advertising campaign. Advertising, public relations, and publicity are all communication processes. Public relations as a promotional activity can be defined as a set of various activities undertaken by a company aimed at building a trust-based relationship between a company and its employees, shareholders, current and potential consumers, suppliers, banks, stock exchanges, various institutes, business partners, chambers of commerce, research institutions, measurement boards, governmental bodies and the public at large, generating goodwill, and gaining favourable publicity and perception of the company and its business (Meler, 2002: 338).

Public relations is a bridge-builder building relationships between a company and its environment. The most common goals of public relations are building a positive reputation of a company or an institution; building a positive image of management team members; raising public awareness and building a positive image of the brand, types of products and services and the company that produces/provides them. Furthermore, public relations is aimed at building a distinctive public reputation that will help the company gain a competitive advantage; adding value to the company; supporting the pursuit of other business goals and strengthening the positive public attitudes; creating a favourable climate in the company. Other goals include raising 
public interest in the company by changing the narrative; turning negative public attitudes into positive; turning the unknown into the known; creating a better overall image of occurrences that are in any way associated with the operation of the organisation, since its inception to its dissolution (ibid).

Social media enable people to share content, opinions, insights, experiences, and perspectives. This can be referred to as the phenomenon of socialisation of information through social media. The sociability of new media is reflected in various forms of digital inclusion such as participation, collective experience, transparency, connectedness, togetherness, independence, etc. Social media facilitates the sharing of information and content, increases engagement, fosters discussions and consultations, enables the creation of information using creative solutions, and the development of marketing and other campaigns. Social communication tools have the potential to increase awareness of social and professional contact trends. Networking can be personal, corporate, social-oriented, professional-oriented, business-oriented, etc. The Internet has changed public relations, which requires new concepts to be developed in marketing theory and practice. It provides more opportunities, but at the same time requires more creativity.

The use of social media in marketing and promotional activities greatly contributes to the success of a business and facilitates goal achievement. Given the speed at which information is conveyed, the large number of social media users and the low cost of advertising, companies are increasingly turning to social media and including them in their overall marketing plans (ibid). Due to the growing impact of ICTs, the boundaries between organisations are decreasing and organisations are becoming more visible and socially engaged The affinities of different social groups connected through social networks are rapidly becoming a social force in the global economy; they are changing the way we interpret market as well as social trends and developments. Advanced use of social media allows companies to establish and manage a wide range of corporate communication activities. Social media management helps users manage their time and work more efficiently (ibid). Furthermore, it enables effective management of responsive and company-initiated online interactions, in line with all other marketing activities.

Businesses have to learn to leverage the opportunities and respond to the challenges presented by the social media in order to attract and maintain the interest of social media users, interact with them, and engage them. Markets have become conversations, and marketing has become participation because social networks enable consumers to interact with each other and influence each other. Content consumption, as well as time and frequency of use of social media by consumers are outside of the direct control of the management in contrast to traditional integrated marketing communication, where there is a high degree of control over product movement and 
consumer behaviour. This is why managers of companies using social media marketing for promotion of their products and services are rapidly adapting to the new, virtual public and its significant potential enabled by the social media, by shaping consumer discussions in a manner consistent with the company's performance goals (Šiđanin, 2012: 19).

Social media usage is growing very fast, primarily due to increasing number of Internet users and the advances in information and communication technologies. With the help of quality apps for tracking website statistics, companies can now look at different features of users visiting their website, such as country, age, gender, or other criteria. One of the reasons behind the popularity of social media marketing is the fact that it less expensive than traditional marketing methods. The definitions/interpretations of internet marketing vary; however, its main features are interactivity and precision of audience targeting. While there are different opinions on how the Internet affects marketing, online marketing is commonly seen as an extension of traditional marketing using different media. Whereas in traditional mass communication models consumers are a passive audience, the Internet as a marketing channel enables two-way communication.

\subsection{Why do we trust celebrities?}

Odak Krastić and Leš (2014: 119-126) explain why people trust celebrities and how celebrities influence the public by using a new brand on the Croatian market called Freywille as an example. Freywille is a leading Austrian company in the production of luxury enamel jewellery. It has a sales network of more than 100 stores in 35 countries on four continents (Europe, Asia, America, and Australia), and more than 550 employees. The company's luxury stores can be found at the most attractive locations in metropolitan areas around the world and/or airports such as Paris, Milan, London, Hamburg, Berlin, Beijing, Hong Kong, Dubai, Moscow, St. Petersburg, Los Angeles, New York, etc. In February 2012, preparations began for the opening of the first Freywille store in Croatia. In September of the same year, the store opened in Preradovićeva 2, Zagreb. The sales network continues to expand across the world.

Freywille, as a new brand on the Croatian market, has yet to build its image and reputation among consumers and in the media. The experience of the neighbouring Slovenian and Serbian markets has shown that the business strategy wherein Freywille products were associated with celebrities has helped build a positive image and has increased profits. Celebrity endorsement increases credibility and relevance of such products over others and creates a perception of higher quality. Another benefit is that celebrity endorsements attract more media attention. Posts and news that feature celebrities will extend the reach of marketers to the media that do not specialise in fashion. Singer and songwriter Nina Badrić was selected as Freywille's ambassador 
for Croatia. A contract was signed between them, specifying their mutual obligations. A communication plan was made encompassing the following: Ms. Badrić will shoot a fashion editorial wearing Freywille jewellery; the photos will be used in announcing the arrival of a new brand to the Croatian market and presenting Ms. Badrić as the brand ambassador; photos will also be posted on Nina Badrićs social media profiles and website; Ms. Badrić will give interviews in which she will speak positively about Freywille products and jewellery; during her public appearances, Ms. Badrić will be wearing Freywille jewellery allowing paparazzi to take her photos, and so on. The contract stipulates that in any communication in which Ms. Badrić is mentioned, the term 'ambassador' be used - the contract expressly forbids the use of the term 'the face of'. The reason for this is the fact that the term 'the face of' is associated exclusively with physical appearance, while the term 'ambassador' embodies a person engaged in conveying a particular message, which in the case of Freywille is that of humanistic values and philosophy. This case exemplifies how a celebrity has been engaged to reach consumers who support and value her and her opinion, and will therefore buy Freywille products.

\subsection{Celebrity status related to products}

A celebrity ${ }^{1}$ is a famous person or a public figure that attracts a lot of media attention. People can become famous in various ways, for example: as a result of their profession, which is the case with athletes, singers, actors, politicians, media personalities; because of their media appearances, attractiveness, unusual lifestyle, special skills, or by accident. We encounter celebrities in public life, either doing their jobs or at special events. We also see them in newspapers, fashion magazines, tabloids, various other magazines, news, shows, etc. It has become common practice for celebrities to endorse products, services, or brands during their public appearances. They endorse a product or service for a fee or receive products for free. Celebrity culture has pervaded the media and it is becoming increasingly difficult to distinguish between life on social media and reality. The prevalence of entertainment content, and the fact that media content is being increasingly reduced to show business and spectacle are direct consequences of the concept of modern market, including the media market, which entails giving the audience what they want (meeting audience needs), but also creating wants, as well as the commodification process itself. ${ }^{2}$

Drašković notes that in a time when the laws of the market are imposed on all forms of social life, many media forms and popular culture media content are subject

1 Other terms used include public figure, star, famous person, etc.

2 Through commodification, something that has no economic value gains a certain market value, whereby human bodies, cultural characteristics, language, or identity are transformed into consumer goods. 
to commodification. The most illustrative examples of the fusion of the commodified and the spectacular are media stars. Stars are spectacular representations of living human beings who project this general banality into images of permitted roles. As specialists of apparent life, stars serve as superficial objects that people can identify with in order to compensate for the fragmented productive specialisations that they actually live, as pointed out by Drašković. Sadly, some people are famous for being famous; it has nothing to do with what they do for a living, which poses a great threat to true cultural values that are not profitable. This creates an impression that anyone can become a star, and every free moment becomes identification with the manipulative reality of the spectacle (Valić Nedeljković and Pralica, 2014: 262-272).

Celebrity endorsement is a form of branding or advertising in which celebrities promote a product, service, or brand by using their social status. Celebrity branding can take several forms - from the appearance of a celebrity in advertisements, to a celebrity attending PR events, creating his or her own line of products or services, or using his/her name as a brand. Another popular method involves celebrities lending their name to promote a line of products/services. ${ }^{3}$ Famous actors, singers, and models are frequently signed to advertise brands of more or less well-known companies, because when the brand's target audience sees their favourite celebrity promoting a particular product or service, they wish to buy it too. Sometimes only the celebrity's voice is used in commercials, because some celebrities have distinct voices which people recognise without seeing their faces. More and more, companies are featuring celebrities in their advertisements to increase brand awareness, appeal and relevance. Companies engage celebrities because of their good communication skills, body language, popularity, attractiveness, intelligence, wit, or their sense of style, which make them perfect for a particular advertisement. Companies choose their celebrity endorsers carefully based on a survey of the target group they want to reach. There are specialised companies that research the market to identify the celebrity that would be the best fit for a particular advertising campaign. Not only do these professionals analyse the celebrity's attributes and characteristics, but they also design an advertisement to fit the celebrity perfectly.

Celebrity endorsement is used for various reasons. One of them is the fact that people look up to celebrities and want to emulate them. However, if a celebrity has endorsed many products, his/her credibility could be questioned because it becomes evident that they are doing it for the money, which in turn questions the truthfulness of their testimonials or endorsements. Celebrities play a very important role in promoting different brands. They have the power to make or break a brand. According to Florjanić, one in four advertisements features a celebrity today, while in 1995, a celebrity appeared in every eighth advertisement. Although these data refer to consumer

$3 \quad$ Most commonly for perfumes and clothes. 
goods and services, celebrities are increasingly associated with luxury brands. One of the reasons marketers use celebrities in brand promotion is to make their marketing message stand out from the marketing clutter and to build brand credibility. In addition, celebrity advertising contributes to raising brand awareness, and when it comes to new luxury brands, it helps position and reposition existing brands, sustain a brand aura, revive a forgotten brand, and improve global brand recognition.

There are various ways in which celebrities can be used to advertise brands. In addition to the most commonly used newspaper and television ads, products can be associated with celebrities by featuring them in television shows, especially in sitcoms or soap operas. The appearance of celebrities in designer clothes or with fashion accessories at various venues and events is becoming more and more popular. Increasingly, celebrities, who are constantly followed by photographers, are being paid to use the products of a certain brand in their daily lives, thus giving the impression that these brands are an integral part of a particular lifestyle. Often luxury brands are also mentioned in songs by famous artists. Celebrity's personality and status are transferred to the brand they advertise, attributing to it the success, wealth, beauty, talent, glamour and style. When selecting a star to advertise a particular brand, it is important to choose a person who has a reputation for being honest and credible, whose talent or expertise is unquestionable; who is well-known and respected worldwide; who has not had any major ups and downs in his/her life, and whose personality matches the personality of the brand. The celebrity should not overshadow the endorsed brand, especially when it comes to newer or less well-established brands. Brands need to maintain and improve the quality of their products after the completion of celebrity endorsement campaigns because consumer expectations have increased.

The relationship between celebrities and the brand they represent and promote is usually regulated by sponsorship or endorsement deals. A natural or legal person who has the right to represent a certain brand of product enters into a contract with another natural or legal person who, by virtue of his/her character, style, distinctiveness, elegance and positive public image, can contribute to brand recognition and market positioning, and increase product demand and price. Under the sponsorship deal, the sponsor undertakes to pay a certain amount of money to the celebrity and supply him/her with their latest products, while the celebrity undertakes to wear a particular brand at every public appearance and is not allowed to wear or present a competitive product or a part of it.

\subsection{Brand ambassador, part of a team}

According to Penović et al. (2014), brand ambassadors, as a type of personal marketing with significant commercial potential in the digital society, are an extremely valuable category of social network users that every business wants to have on their 
side. They share positive opinions and experiences about a company, giving a whole new meaning to the word-of-mouth. The goal of any company is to identify individuals in the community who advocate for it, either on the market or on social media platforms, recruit them, and adequately reward them for their engagement. In building their image using digital technologies, individuals are rewarded for their efforts by the brands they represent and whose values they convey. Soliciting a known influencer to act as a company's PR person has proven to be successful in generating business outcomes. Influencers are individuals who have a large number of followers, views, or shares on social media. They post content daily, much of which is about their private life. Followers feel close to them, as if they have known each other for years, making them believe they are trustworthy and credible sources of information. The brands have recognised this trend and decided to leverage it by engaging famous influencers to promote their products or services. When a brand identifies a person, who reflects the brand's values, and if they agree to cooperate, that person becomes a brand ambassador. The company provides its products or service to influencers/brand ambassadors who promote them on their accounts for a fee. This method has proven to be more cost-effective than traditional advertising. Human brands function in the same way as product and service brands. They convey values and perceptions that influence a specific target market (Dugalić and Ivić, 2015: 207-216).

Using Nike as an example, Vrban (2014: 45-59) explains that a brand represents the relationship established between a person wearing, for instance, Nike sneakers, and Nike, the company. Such a relationship is meaningful for both sides, the company, and its customer. Marketing and advertising campaigns present Nike as an active, determined, sports-oriented company. The company highlights the success of athletes wearing Nike gear. At the same time, the ad sends a message that famous football players are emotionally attached to Nike because they feel comfortable, safe, and confident wearing their gear. The aim is to establish that emotional connection with the customers. Young people who admire the success of football players or look up to them will want to buy Nike sneakers. This example shows how celebrities influence consumer choices.

\subsection{The importance of choosing the right celebrity endorser}

When engaging celebrities to endorse their products or services, one of the major concerns of companies are potential scandals. Inappropriate behaviour of engaged celebrities can in many ways harm a brand, reduce the number of active consumers, but also drive away potential consumers who were willing to give their trust to the brand. For example, Pepsi made a bad endorsement decision by signing Michael Jackson to be the face of their campaign, but then had to drop him when he was accused of child abuse. The same happened to Britney Spears who was dropped from Coca-Cola ad- 
vertising after her private struggles and public incidents made the tabloids and she was repeatedly seen ordering the rival drink Coke, in violation of her contract. An example of good endorsement deal in Croatia is the long-standing collaboration between Severina (a popular singer) and shoe brand Mass. Mass has seen an increase in sales precisely because of the good choice they made.

\section{Consumer satisfaction and loyalty}

One of the many social roles that humans play is that of consumer. In a market society, humans satisfy their economic needs through their role as consumers. The consumer, as an individual or a household that has a certain income and purchasing power, is in the market for a specific amount and quality of consumer goods. It is important to distinguish regular from occasional, large from small, and satisfied from dissatisfied consumers. A satisfied consumer will buy a product or service again; he/ she will share positive experiences with others, and will stay loyal to the company and brand (Vugrinec-Hitrec, 1992: 51-64).

The behaviour of consumers in the consumer and industrial goods market is one of the variables of marketing management planning that cannot be controlled. It has a dominant influence on the realisation of short- and long-term strategic marketing plans. The following factors affect the behaviour of consumers on the consumer goods market: consumer traits, e.g. motivation, perceptions, attitudes, opinions, attributes, lifestyle, experience, etc. as well as socio-cultural factors, which include their family, reference groups, social class, culture, subculture, etc. Consumer behaviour is defined as the behaviour that consumers display in searching for, purchasing, using, evaluating, and disposing of products and services that they expect will satisfy their needs. Accurate and continuous monitoring of the purchase process and identification of the factors in that process are instrumental in the success of a business. By studying consumer behaviour, businesses explore how individuals make decisions to spend their money, time, and energy on specific products. Consumers vary in their age, income, education level, mobility patterns, and taste. Consumer behaviour is dynamic. Individual consumers, consumer groups and society at large are constantly changing and evolving, which is an important factor that has to be taken into consideration when studying consumer behaviour and developing a marketing strategy. Consumer behaviour also includes the exchange of information between individuals (Pindyck and Rubinfeld, 2005: 1-2).

Given the strong competition in all branches of commerce and production, it is imperative for companies to adapt to the tastes of consumers. In other words, marketers must learn to think like consumers. Consumers are becoming increasingly aware of the variety of products available, so it is becoming more and more difficult to 
attract them. The products sell easier if manufacturers bring them closer to consumers (Kovačić and Đukec, 2016). This is why one of the main functions of marketing is to continuously study and monitor consumer needs and wants as well as the factors that influence their behaviour, i.e. explore how consumers make the decision to buy a particular product. Another important task of marketing is developing an adequate marketing mix which will achieve a high level of consumer satisfaction and help a company stay ahead of the competition (Kesić, 2006).

Consumer behaviour is very complex. Hence, it is crucial for companies to study and understand it, and find ways to influence it. The latter can be done by tailoring elements of the marketing mix to the consumer needs. Success is possible as long as there are needs. If the need for a certain product or service is not expressed, i.e. if it is only latent, the manufacturer can initiate communication about a specific product to move the needs from our subconscious to our conscious mind. There are numerous communication techniques marketers use to influence consumers to act in ways that benefit their company. Communication methods and direct selling are adapted to the modern consumer by extending the product range, offering new and simpler solutions, increasing the utility of existing products, and providing customer service. Kesić and Piri Reich point out that modern living trends require different marketing approaches for successful performance in the market (Previšić et al., 2004: 111).

\subsection{The impact of consumer satisfaction on purchase decision}

Factors that affect customer satisfaction include, inter alia, the fulfilment of customer expectations in terms of characteristics of a process or product. Customer satisfaction strategy must keep in check the factors that may affect customer satisfaction unfavourably, making sure to deliver a great customer experience. Thus, organisations need to identify these factors and determine the extent to which they affect customer behaviour based on a thorough marketing and requirement analyses. The goal is to identify the factors that drive customer satisfaction and then successfully manage and execute a customer experience strategy (Ristić, 2005: 1-9). Characteristics of products or processes that customers did not expect or ask for in a product but are delighted by them if they are provided are referred to as wow factors. Customer delight is achievable; however, to achieve it, marketers must identify and keep up with the ever-changing customer preferences and wants. This is a complex task, which can be accomplished by means of direct digital marketing (ibid).

\section{Research methodology and results}

The results of the research are based on the data obtained through a specially designed survey questionnaire. A total of 190 respondents were surveyed. Most respond- 
ents are aged 26-35. Almost half of them (45,8 \%) hold a master's or doctoral degree. The aim of the research is to determine how consumers make decisions to buy a particular product and to what extent their decisions are influenced by the fact that the same product is used by a celebrity. The research seeks to determine how a celebrity's image influences the purchase of a product and the satisfaction/dissatisfaction with a brand and its quality. The following research hypotheses are proposed:

Hypothesis H1. The use of celebrities in advertising attracts consumer attention.

Explanation for hypothesis H1: Consumers look up to celebrities and want to emulate their behaviour and appearance. They often want to have the same clothes or a hairstyle as the featured celebrity.

Hypothesis H2. The use of celebrities in advertising drives consumers' purchase decisions.

Explanation for hypothesis H2: Some media post articles and interviews with details about the celebrity's hairstyle or wardrobe, sharing with consumers where the clothes can be purchased and at what price, who designed them, etc. In doing so, they drive consumers' purchase decisions.

Hypothesis H3. Celebrity's image affects product image.

Explanation for hypothesis H3: The popularity of the celebrity used for product endorsement increases the popularity of the endorsed product. Thus, the image of the celebrity must match the desired image of the product. A positive image is created through quality management.

Hypothesis H4. Product brand satisfaction increases brand loyalty.

Explanation for hypothesis H4: Loyalty implies a consumer's commitment to a particular brand based on a positive attitude and is reflected in re-purchase. This indicates that satisfaction with the purchased product implies a positive attitude towards the product brand.

\subsection{Research results}

The results of the survey are based on the data obtained through a questionnaire designed for the purpose of this research. A total of 190 respondents were surveyed, of which $55,8 \%$ are women and $44,2 \%$ are men. 
Table 1. Demographic profile of respondents $(n=190)$

\begin{tabular}{|ccc|}
\hline GENDER & $n$ & $\%$ \\
\hline Male & 106 & $55,80 \%$ \\
\hline Female & 84 & $44,2 \%$ \\
\hline AGE & & \\
\hline $18-25$ & 18 & $9,48 \%$ \\
\hline $26-35$ & 85 & $44,74 \%$ \\
\hline $36-45$ & 40 & $21,05 \%$ \\
\hline $46-55$ & 27 & $14,21 \%$ \\
\hline $56+$ & 20 & $10,52 \%$ \\
\hline EDUCATION LEVEL & 0 & $0 \%$ \\
\hline Primary & 14 & $6,9 \%$ \\
\hline Secondary & 176 & $93,1 \%$ \\
\hline Tertiary or higher & & \\
\hline
\end{tabular}

Data were collected by means of a survey, which was divided into two sections. Most of the questions were Likert-type questions, where the respondents were asked to indicate their level of agreement with a statement on a scale of 1 to 5 (1 being strongly disagree and 5 being strongly agree). Twenty variables were constructed that were considered to best represent the role and importance of celebrities in advertising, in terms of driving contemporary consumers' purchase decisions, and affecting customer satisfaction and loyalty. The variables were tested using exploratory factor analysis.

The survey found that $35,5 \%$ of the respondents agree that advertising plays an important role in purchase decisions. Clearly, advertising sells products. The first hypothesis, which proposes that the use of celebrities in advertising attracts consumer attention, has been confirmed because $45,3 \%$ of the respondents agree and 38,4 \% completely agree with the statement "I believe that celebrity endorsements have an impact on the sale of the endorsed product." Consumers look up to celebrities and often want to emulate them by wearing the same outfit or having the same hairstyle as their favourite celebrity. Hypothesis 2, suggesting that the use of celebrities in advertising drives consumers' purchase decisions, has also been confirmed. $41,6 \%$ of the respondents agree and 28,4\% strongly agree with the statement "Endorsements by celebrity bloggers who interact with a large number of fans can affect product sales". In some of these blogs, celebrities share whose clothes they are wearing, or where they have purchased their outfit, and similar details, thus encouraging consumers to buy them.

The third hypothesis, proposing that a celebrity's image influences the image of a product, has also been confirmed as $40 \%$ of the respondents completely agree that a negative image of a celebrity can adversely affect the sale of products endorsed, while 
$30 \%$ of them believe that celebrities prone to scandals do not make good brand ambassadors. $31,10 \%$ of the respondents agree with the statement that a celebrity endorsing a particular product is interesting to the media and as such is ideal for promoting products, while $44,20 \%$ partly agree. The popularity of celebrities increases the popularity of the product. Thus, the celebrity image must match the desired image of the product. Hypothesis 4, suggesting that product brand satisfaction increases brand loyalty, has also been confirmed as $49,5 \%$ of the respondents are somewhat satisfied with the purchase of branded products, while $32,10 \%$ are loyal to the same brand. Loyalty implies a consumer's commitment to a particular brand based on a positive attitude and is reflected in re-purchase. This indicates that satisfaction with the purchased product implies a positive attitude towards the product brand. Based on the data collected, it may be concluded that celebrities have a great influence, both positive and negative, on product sales. Different people have different opinions. People also see things differently. In order for the product to be well accepted by consumers and for sales to grow, it is important to choose the right celebrity endorser. If done well, celebrity endorsements will attract new customers and build consumer trust which will in turn lead to loyalty. Loyalty will lead to increased customer retention and thus to long-term profitability.

\section{Conclusion}

Product branding is not a new phenomenon. Brands have been used for centuries to show ownership or identify the manufacturer. The practice has evolved into product branding and product management. A brand is a combination of tangible and intangible features of a product or service that identify it. It is used to attract and communicate with consumers and facilitate the consumer decision-making process. When entering a new market, every for-profit organisation, whose target audience are consumers, must focus its communication activities on adding value to the product and/ or company name, i.e. branding that will have a positive influence on consumer actions. Given the saturation of the market with new products and brands, the success of branding depends on the ability of a company to use different techniques and skills as part of its brand strengthening activities. This means that in addition to marketing mechanisms such as launching, promoting and selling, the company should use public relations to create a climate in which it will perform better, establish and maintain a positive relationship and mutual trust with target groups, and add value to the company itself. More specifically, public relations rely on the use of communication skills that help develop corporate identity and convey it to customers and the public at large, which is a precondition for creating a positive image and turning it into a positive reputation. Choosing the right celebrity endorser is crucial as this has a significant 
impact on product sales. People trust the celebrity and are thus inclined to buy and use the endorsed product. People are more likely to buy a product if they have seen a good advertisement for that product. If a celebrity is featured in the advertisement, consumers are even more likely to buy it because it was recommended by a credible source. The research results indicate that brand ambassadors, i.e. public figures are a vital element of contemporary marketing strategies.

\section{References}

1. Dugalić, S. and Ivić, J. 2015. Angažovanje slavnih sportista u promociji proizvoda i usluga. Marketing, 46 (3): 207-216.

2. Dvorski, S., Vranešević, T. and Dobrinić, D. 2004. Suvremene tendencije u razvitku marketinga - osvrt na direktni marketing. Ekonomski pregled, 55 (7-8): 619-640.

3. Ferenčić, M. 2012. Marketinška komunikacija u digitalnom svijetu. Praktični menadžment, 3 (5): 42-46.

4. Filipović, V. 2008. Brend menadžment. Beograd. http://marketing-pr.fon.rs/webroot/uploads/Brand\%20Management\%20-\%20Skripta.pdf, retrieved 4. 12. 2018.

5. Golob, M. 2016. Mobilni marketing kao sastavni dio integrirane marketinške komunikacije. Zbornik Veleučilišta u Rijeci, 4 (1): 147-158.

6. Ilić, D. and Marković, B. 2014. Značaj upotrebe internet društvenih mreža u procesu dostizanja održive konkurentne prednosti. Sinteza, 82-87.

7. Ištvanić, M., Crnjac Milić, D. and Krpić, Z. 2017. Digital Marketing in the Business Environment. International Journal of Electrical and Computer Engineering Systems, 8 (2): 37-75. https://hrcak.srce.hr/192913

8. Jukić, D. 2017. Dekonstrukcija marke utemeljene na potrošaču. Trgovačka i komercijalna škola "Davor Milas", 55. https://www.google.hr/search?source=hp\&ei=iuq-XJabN6KqrgS635TYCQ\&q=Jukić\%2C+D.\%282017\%29.+Dekonstrukcija+marke+utemeljene+na+potrošaču\%2C+Trgovačka+i+komercijalna+škola+\%27\%27Davor+Milas$\% 27 \% 27 \% 2 \mathrm{C}+$ Osijek\&btnK=Google+

9. Keller, K. 2003. Strategic Brand Management. Prentice Hall.

10. Kesić, T. 2003. Integrirana marketinška komunikacija. Zagreb: Opinio d.o.o.

11. Kesić, T. 2006. Ponašanje potrošača. Zagreb: Opinio d.o.o.

12. Kotler, P. and Keller, K. L. 2008. Upravljanje marketingom. Zagreb: Mate d.o.o.

13. Kotler, P., Keller, K. and Martinović, M. 2014. Upravljanje marketingom. Zagreb: Mate d.o.o.

14. Lacković Z. and Andrlić B. 2007. Osnove strateškog marketinga. Požega: Veleučilište u Požegi.

15. Lijović, B. 2012. Identitet marke proizvoda - čimbenik uspješnog tržišnog položaja marke proizvoda. Ekonomki vjesnik, XXV (2): 1-4.

16. Meler, M. 2002. Marketing. Osijek: Grafika.

17. Ninčević, Š., Krajnović, A. and Bosna, J. 2015. The role and importance of mobile marketing in the system of marketing management. Marketing, 2 (1): 668-678. 
18. Odak Krasić, S. and Leš, M. 2014. Specifičnost komuniciranja prilikom uvođenja nove modne marke na hrvatsko tržište - Studija slučaja Freywille. Praktični menadžment, 5 (1): 119-126.

19. Orlović, M., Krajnović, A. and Bosna, J. 2014. Suvremene marketinške strategije i brendiranje proizvoda kao izazovi globalnog marketinga. Praktični menadžment, 5 (2): 115-123.

20. Pavković, V. and Vlastelica, T. 2016. Evolucija medijskih komunikacija kroz istorijske i civilizacijske epohe. Marketing, 42-56.

21. Penović, A., Ličina, B., Cetinić, M. and Rašeta, I. 2014. Pobijedite Internet (ili će Internet pobijediti vas). Zagreb: Jasno i Glasno d.o.o.

22. Pindyck, R. and Rubinfeld, D. L. 2005. Mikroekonomija: proizvođači, potrošači i konkurentna tržišta. Zagreb: Mate d.o.o.

23. Previšić, J. et al. 2004. Marketing. Zagreb: Adverta d.o.o.

24. Projović, I. and Popović Šević, N. 2013. Marketinške komunikacije u savremenom poslovanju. Časopis za ekonomiju i tržišne komunikacije / Economy and Market Communication Review, 5 (1): 105-122.

25. Rajh, E. 2002. Development of a scale for measuring customer-based brand equity. Ekonomski pregled, 53 (7-8): 770-781.

26. Ristić, J. 2005. Mjerenje zadovoljstva kupaca / Customer satisfaction measurement. Festival kvaliteta 2005, 32. Nacionalna konferencija o kvalitetu. Kragujevac: AOS. http:// www.cqm.rs/2005/fq2005/SEKCIJA\%20H\%20-\%20\%20Rani\%20radovi/24\%20-\%20 J.\%20Ristic.pdf

27. Sinčić Ćorić, D. and Roglić, M. 2015. Osobnost luksuzne modne marke. Ekonomski pregled, 66 (2): 138-155.

28. Šiđanin, I. 2012. Menadžment socijalnih medija i medijsko okruženje / Social media management and media environment. Škola biznisa, 1-7.

29. Šunić, Š. 1994. Marketing strategija uslužnih djelatnosti. Tour. hosp. manag., 1 (1): 191200.

30. Valić Nedeljković, D. and Pralica, D. 2014. Digitalne medijske tehnologije i društveno-obrazovne promene. Zbornika radova: Univerzitet u Novom Sadu, Filozofski fakultet, Odsek za medijske studije. Novi Sad, 279-389. http://odsek.medijskestudije.org/ wp-content/uploads/2011/03/Zbornik-Digitalne-tehnologije-FINAL.pdf

31. Vojvodić, K. and Nižić, M. 2014. Diferenciranje maloprodavača putem premijskih trgovačkih maraka. Praktični menadžment, 4 (1): 27-32.

32. Vranešević, T. 2016. Upravljanje markama - Brand Management. Zagreb: Accent.

33. Vranešević, T. and Marušić, M. 2003. Mjerenje vrijednosti marke. Zbornik Ekonomskog fakulteta u Zagrebu, 1 (1): 129-148.

34. Vrban, S. 2014. Brendiranje obrazovanja. Andragoški glasnik, 18 (2): 45-60.

35. Vrcelj, S. 2016. Izazovi kojima su pedagozi izloženi u savjetodavnom radu - globalizacijski kontekst i (anti)vrijednosti. Školski vjesnik, 65 (1): 59-73.

36. Vukman, M. and Drpić, K. 2014. Utjecaj internet marketinga na razvoj brenda turističke destinacije. Praktični menadžment, 141-145.

37. Vuković, J. 2017. Komunikacija s klijentima sa ciljem stvaranja prepoznatljivog benda. Specijalistički diplomski stručni rad. Pula: Visoka tehničko-poslovna škola s pravom javnosti.

38. Zavišić, Ž. 2017. Osnove marketinga. Zagreb: Visoka poslovna škola Zagreb. 


\section{Uloga i važnost slavnih osoba u postizanju zadovoljstva suvremenih potrošača \\ Sažetak}

Cilj je ovoga istraživanja na temelju prikupljenih podataka putem primarnog te sekundarnog istraživanja dobiti uvid u lojalnost potrošača na tržištu prema utjecaju slavnih osoba i marki. Istraživanje također obuhvaća pojmovnu važnost marke te odnos potrošača prema markama i slavne osobe u oglašavanju. Marka je prepoznatljiva oznaka ili ime nekog proizvoda i usluga koji se uvijek smatraju kvalitetnim. Slavne osobe postale su neizostavan atribut u suvremenom oglašavanju i distribuciji marki, odnosno brendova na tržištu. Investiranje u oglašavanje putem novih medija i društvenih mreža postalo je obavezni dio u marketinškoj komunikaciji.

Ključne riječi: slavna osoba, oglašavanje, upravljanje markom, zadovoljstvo potrošača, lojalnost potrošača 